GRASAS Y ACEITES 67 (2)

April-June 2016, e133

ISSN-L: 0017-3495

doi: http://dx.doi.org/10.3989/gya.0629152

\title{
Effect of fat replacement by olive oil on the physico-chemical properties, fatty acids, cholesterol and tocopherol content of pâté
}

\author{
R. Domínguez ${ }^{\mathrm{a}}$, R. Agregán ${ }^{\mathrm{a}}$, A. Gonçalves ${ }^{\mathrm{b}}$ and J.M. Lorenzo ${ }^{\mathrm{a}, \bowtie}$ \\ ${ }^{a}$ Centro Tecnológico de la Carne de Galicia, Rúa Galicia N 4, Parque Tecnológico de Galicia, \\ San Cibrao das Viñas, 32900 Ourense, Spain \\ ${ }^{b}$ Escola Superior Agrária, Instituto Politécnico de Bragança, Campus Sta. Apolónia Apta 1172 5301-855 Bragança, Portugal \\ ${ }^{\square}$ Corresponding author: jmlorenzo@ceteca.net
}

Submitted: 10 June 2015; Accepted: 30 November 2015

SUMMARY: The present study investigates the effects of olive oil when used as back fat replacers on the physico-chemical properties, fatty acids, cholesterol and $\alpha$-tocopherol content of pâté. The replacement of back fat by olive oil at 50 and $100 \%$ did not affect the moisture, fat or protein contents, while it increased yellowness. According to texture parameters, reformulated pâté presented lower values for hardness, cohesiveness, gumminess and chewiness. The use of olive oil significantly $(P<0.05)$ affected the fatty acid content. The amount of MUFA increased, while the content of SFA and PUFA decreased as the back fat was replaced by olive oil. The replacement of fat resulted in an improvement in all nutritional indexes. Atherogenic and thrombogenic indexes decreased while the $\mathrm{h} / \mathrm{H}$ ratio increased with fat replacement. At the same time, the content of $\alpha$-tocopherol increased and the amount of cholesterol decreased with the addition of olive oil. Therefore, olive oil provides pâté with high levels of C18:1n9c and MUFA, natural antioxidants such as $\alpha$-tocopherol and reduces cholesterol levels. As a general conclusion, the replacement of back fat by olive oil allows us to obtain a healthier product.

KEYWORDS: Fat replacement; Nutritional value; Olive oil; Pâté

RESUMEN: Efecto de la substitución de grasa por aceite de oliva en las propiedades físico-químicas, ácidos grasos y contenido de colesterol y tocoferol de pâté. Este estudio se realizó para investigar el efecto del aceite de oliva como substituto de grasa dorsal sobre las propiedades físico-químicas, ácidos grasos y contenido en colesterol y $\alpha$-tocoferol de pâté. La substitución de la grasa dorsal por aceite de oliva al 50\% y al 100\% no afectó al contenido de humedad, grasa y proteína, mientras que incrementó la intensidad de color amarillo. Con respecto a los parámetros de textura, el pâté reformulado presentó una menor dureza, cohesividad, gomosidad y masticabilidad. El uso de aceite de oliva también afectó significativamente al perfil de los ácidos grasos. El contenido de ácidos grasos monoinsaturados incrementó, mientras que el contenido de ácidos grasos saturados y poliinsaturados disminuyó a medida que la grasa dorsal fue reemplazada por aceite de oliva. El reemplazo de la grasa de cerdo mejoró todos los índices nutricionales, disminuyendo los índices aterogénico y trombogénico mientras que aumento el ratio h/H. A su vez, el contenido en $\alpha$-tocoferol incrementó y la cantidad de colesterol disminuyó con la adición de aceite de oliva. Por tanto, el uso de aceite de oliva nos proporciona un pâté con altos niveles de C18:1n9c y ácidos grasos monoinsaturados, antioxidantes naturales como $\alpha$-tocoferol y una menor cantidad de colesterol. Como conclusión general, el reemplazo de grasa por aceite de oliva nos permite obtener un producto más saludable.

PALABRAS CLAVE: Aceite de oliva; Pâté; Substitución de grasa; Valor nutricional

Citation/Cómo citar este artículo: Domínguez R, Agregán R, Gonçalves A, Lorenzo JM. 2016. Effect of fat replacement by olive oil on physico-chemical properties, fatty acids, cholesterol and tocopherol content of pâté. Grasas Aceites 67 (2): e133. doi: http://dx.doi.org/10.3989/gya.0629152.

Copyright: (C) 2016 CSIC. This is an open-access article distributed under the terms of the Creative Commons Attribution-Non Commercial (by-nc) Spain 3.0 Licence. 


\section{INTRODUCTION}

Pâté is a very popular and cheap cooked meat product manufactured worldwide (Delgado-Pando et al., 2011) and forms part of the gastronomic culture in some countries such as Spain, France, Germany and Denmark (Martín et al., 2009). However, this product presents some negative health concerns related to its fat content and fatty acid profile (Jiménez-Colmenero, 2007). Therefore, the reformulation of meat must address the lipid fraction both quantitatively and qualitatively, fat reduction and modification of fatty acid composition, respectively. Food technologists have been challenged to develop new meat and fat-based products with improved characteristics for accommodating consumer concerns about the relationship between health and nutrition. For many consumers, reducing dietary fat is a major dietary goal since there is evidence that fat-rich diets cause obesity and they are also directly related to the risk of colon cancer and cardiovascular diseases (Lorenzo et al., 2014). The fat in meat and meat products is one of the components that most exceeds the limits set in nutritional recommendations and needs to be modulated (Salcedo-Sandoval et al., 2014). In this regard, the meat industry is looking for strategies for foodstuffs with lower fat content, lower levels of saturated fatty acids (SFAs), higher levels of polyunsaturated fatty acids (PUFAs), or monounsaturated fatty acids (MUFAs) (Martín et al., 2008). Achieving healthier lipid meat products implies reducing fat and/or replacing animal fat with vegetable and/or marine oils which could reduce SFAs and cholesterol and increase MUFAs and PUFAs (specially oleic acid and n-3 PUFAs) (Salcedo-Sandoval et al., 2014).

In reformulated meat products not only nutritional improvement should be taken into account. The development of products with fat reduction, must also address a number of factors that will influence the fat reduction strategy, quality factors and the final consumer acceptability (Lorenzo and Pateriro, 2013). This type of products requires modifications in its composition and nature which in turn will affect quality attributes such as color, flavor, texture and binding properties. Low-fat meats products should offer attributes that are the same as those of the traditional products and perceived with an improvement in the health characteristics attributed to them (Sampaio et al., 2004).

One of several purposes involving fat replacers is to facilitate a reduction in total and saturated fat consumption (Sampaio et al., 2004). Partially substituting pork back fat with other ingredients is a possibility for reducing the negative effects derived from the high fat content of meat products, which shows some negative aspects from the nutritional point of view (Muguerza et al., 2001). The incorporation of olive oil into meat products may have a positive effect on consumer health because of its cholesterol-lowering effect contrary to animal fats, which are predominantly saturated (Bloukas et al., 1997). Olive oil is the most monounsaturated vegetable oil and has unique physicochemical and sensorial characteristics (Bloukas et al., 1997). It is highly appreciated for its delicious taste and aroma as well as nutritional benefits related to the high content of oleic acid and also to the balanced ratio of saturated and polyunsaturated fatty acids. The unique character of olive oil is attributed to its phytosterols, together with fatty acids and minor constituents such as phenolic compounds associated with taste (bitter and pungent notes) and volatile compounds which are responsible for aroma (ReboredoRodríguez et al., 2014). The major components known as the saponifiable or glyceride fraction and glycerols represent $>98 \%$ of total oil weight and the minor constituents in olive oil, present about $2 \%$ of the oil's weight, have substantial vascular and cardio-protective effects (Huang and Sumpio, 2008). Its beneficial effects on coronary heart disease risk factors are recognized and are often attributed to its high levels of MUFA. Olive oil is also rich in tocopherols which act as antioxidants such as the phenolic substances (Bloukas et al., 1997) and several components have beneficial health effects on the atherosclerotic (especially oleic acid and the polyphenols) and thrombotic pathways, which include lipid oxidation, hemostasis, platelet aggregation, coagulation, and fibrinolysis (Huang and Sumpio, 2008). The antioxidant effect of olive oil may explain the protective effect of virgin olive oil on blood pressure levels.

Thus, the aim of this research was to study the effect of pork back fat replacement by olive oil on the physico-chemical $(\mathrm{pH}$, chemical composition, color and texture parameters) and nutritional properties (fatty acid profile, cholesterol, tocopherol content and nutritional indexes) of pâté.

\section{MATERIAL AND METHODS}

\subsection{Manufacturing of the pâté}

The pâtés were prepared in the pilot plant of the Meat Technology Center of Galicia. The recipe used for the preparation of pâtes is presented in Table 1. Pork back fat and pork meat were provided by a local slaughterhouse. Olive oil was acquired in a local supermarket ( $72 \%$ of oleic acid). The back fat and lean pork were pre-cooked at $76{ }^{\circ} \mathrm{C}$ (core temperature) in a hot water bath for $1 \mathrm{~h}$. A preemulsion of the fat source (pork back fat, olive oil or the appropriate mixture according to the batch), water (obtained from the pre-cooking) and sodium caseinate was carried out for $1 \mathrm{~min}$ in a cutter (Talsa, mod K30, Valencia, Spain). Subsequently, the rest of the ingredients (lean meat, chestnut flour, 
TABLE 1. Recipe used for the preparation of pâtés with different olive oil contents

\begin{tabular}{lrrr}
\hline & \multicolumn{3}{c}{ Fat replacement } \\
\cline { 2 - 4 } Ingredients $\left(\mathbf{g} \cdot \mathbf{1 0 0} \mathbf{g}^{-\mathbf{1}}\right)$ & $\mathbf{0} \%$ & $\mathbf{5 0} \%$ & $\mathbf{1 0 0} \%$ \\
\hline Lean & 73.29 & 73.29 & 73.29 \\
Back fat & 12.00 & 6.00 & 0.00 \\
Olive oil & 0.00 & 6.00 & 12.00 \\
Caseinate & 2.00 & 2.00 & 2.00 \\
Chestnut flour & 1.00 & 1.00 & 1.00 \\
NaCl & 1.25 & 1.25 & 1.25 \\
White pepper & 0.07 & 0.07 & 0.07 \\
Black pepper & 0.07 & 0.07 & 0.07 \\
Nutmeg & 0.20 & 0.20 & 0.20 \\
Oregano & 0.07 & 0.07 & 0.07 \\
Garlic & 0.05 & 0.05 & 0.05 \\
Water & 10.00 & 10.00 & 10.00 \\
\hline
\end{tabular}

$0 \%$ : Control batch (elaborated without olive oil).

salt, white and black pepper, nutmeg, oregano and garlic) were added and chopped until a homogeneous batter $(2 \mathrm{~min})$ was obtained. During the fat pre-emulsion, the temperature of the raw batter was always above $40{ }^{\circ} \mathrm{C}$ and during chopping, the temperature was maintained at around $46^{\circ} \mathrm{C}$. The pâtés were manually distributed into metal cans until completely full $(250 \mathrm{~g})$ and these were then hermetically closed prior to thermal treatment $\left(78^{\circ} \mathrm{C} / 75^{\prime}\right)$. The samples were cooled in a blast chiller $\left(-21^{\circ} \mathrm{C} / 30^{\prime}\right)$ and then analyzed.

\subsection{Chemical composition and $\mathrm{pH}$ values}

Moisture, fat and protein were determined according to the ISO recommended standards. The moisture content was determined by drying in an oven at $105^{\circ} \mathrm{C} \pm 2{ }^{\circ} \mathrm{C}$ (ISO 1442:1997); the nitrogen content was determined by the Kjeldahl method and protein content estimated by multiplying the nitrogen content by 6.25 (ISO 1443:1973); the fat content was determined by the Soxhlet method using petroleum ether (ISO 937:1978). The $\mathrm{pH}$ of the samples was measured using a digital $\mathrm{pH}$ meter (model 710 $\mathrm{A}+$, Thermo Orion, Cambridgeshire, UK) equipped with a penetration probe.

\subsection{Color parameters}

Color parameters were measured using a portable colorimeter (Konica Minolta CM-600d, Osaka, Japan) with a pulsed xenon arc lamp filtered to illuminant D65 lighting conditions, with $0^{\circ}$ viewing angle geometry and $8 \mathrm{~mm}$ aperture size, was used to estimate the meat color in the CIELAB space: lightness, $\left(\mathrm{L}^{*}\right)$; redness, $\left(\mathrm{a}^{*}\right)$; yellowness, $\left(b^{*}\right)$. The color was measured in three different points of each sample. Before each series of measurements, the instrument was adjusted using a white ceramic tile.

\subsection{Texture measurement}

A Texture Analyzer (TA-XT.plus, Stable Micro Systems, Vienna Court, UK) was used. The penetration test was carried out at room temperature $\left(22^{\circ} \mathrm{C}\right)$ and performed with a $6 \mathrm{~mm}$ diameter penetration probe linked to a $5 \mathrm{~kg}$ cell at a velocity of $0.8 \mathrm{~mm} \cdot \mathrm{s}^{-1}$ and for a distance of $8 \mathrm{~mm}$. Hardness $(\mathrm{N})$, cohesiveness, elasticity, gumminess $(\mathrm{N})$ and chewiness $(\mathrm{N})$ values were obtained using the available computer software (TEE32 Exponent 4.0.12. Stable Micro Systems, Vienna Court, UK).

\subsection{Cholesterol and tocopherol analyses}

For saponification, $2 \mathrm{~g}$ of homogenized meat sample were placed in duplicate in screw-cap tubes with Teflon lining, to which $0.2 \mathrm{~g}$ L-ascorbic acid and $5 \mathrm{~mL}$ saponification solution were added. The saponification solution, freshly prepared each week, contained $11 \% \mathrm{w} / \mathrm{v}$ potassium hydroxide in a mixture of $55 \% \mathrm{v} / \mathrm{v}$ absolute ethanol and $45 \% \mathrm{v} / \mathrm{v}$ distilled water. The sample was then immediately vortexed in order to avoid meat agglomeration. After vortexing, the air was eliminated from the reaction by displacement with nitrogen gas and the sample was further shanked until the ascorbic acid was completely dissolved. Saponification was carried out in a shaking water bath (THER-SPIN, Orto Alresa, Madrid, Spain) $(200 \mathrm{rpm})$ at $85^{\circ} \mathrm{C}$ for $45 \mathrm{~min}$.

After saponification, samples were cooled in tap water for $1 \mathrm{~min}$. Following cooling, $1.5 \mathrm{~mL}$ of distilled water and $3 \mathrm{~mL}$ of $25 \mu \mathrm{g} \cdot \mathrm{mL}^{-1}$ BHT solution in n-hexane were added (final proportions of $4.5 \mathrm{~mL}$ $\mathrm{H}_{2} \mathrm{O}: 3 \mathrm{~mL}$ ethanol: $3 \mathrm{ml} \mathrm{n}$-hexane; the meat sample was assumed to contribute with $0.5 \mathrm{~mL} \mathrm{H}_{2} \mathrm{O}$ ). The samples were vigorously vortexed and centrifuged at $1500 \mathrm{~g}$ for $5 \mathrm{~min}$, in order to accelerate phase separation. An aliquot of the upper layer (n-hexane) was transferred into a small screw-cap tube with Teflon lining and a spatula-tip of anhydrous sodium sulphate was added. Finally, the tube was briefly shaken and an aliquot of the n-hexane layer was filtered through a $0.45-\mu \mathrm{m}$ hydrophobic membrane into an amber screw-cap vial with a Teflon septum.

The HPLC systems used was an Alliance 2695 model (Waters, Milford, USA) a 996 photodiode array detector (Waters Milford, USA) and a 2475 fluorescence detector (Waters Milford, USA). Empower 2TM advanced software (Waters, Milford, USA) was used to control the system operation and manage the results. The analyses of cholesterol and $\alpha$-tocopherol were performed using a normal-phase silica column (SunFireTM Prep Silica, $4.6 \mathrm{~mm}$ ID $\times 250 \mathrm{~mm}, 5 \mu \mathrm{m}$ particle size, Waters, Milford, 
MA, USA), with UV-Vis photodiode array detection for cholesterol (208 nm) and with fluorescence detection for $\alpha$-tocopherol (excitation at $290 \mathrm{~nm}$ and emission at $327 \mathrm{~nm})$. The solvent ( $2 \% \mathrm{v} / \mathrm{v}$ isopropanol in $\mathrm{n}$-hexane) flow rate was $1 \mathrm{~mL} \cdot \mathrm{min}^{-1}$, the run lasted $17 \mathrm{~min}$ and the temperature of the column oven was adjusted to $25^{\circ} \mathrm{C}$. From each sample 20 $\mu \mathrm{L}$ were injected. The content of cholesterol and $\alpha$-tocopherol were calculated, in duplicate for each sample, based on the external standard technique from a standard curve of peak area $v$ s. concentration.

\subsection{Fatty acid methyl ester analysis}

The total fat was extracted from $15 \mathrm{~g}$ of sample according to the Bligh and Dyer (1959) procedure. Fifty milligrams of fat were used to determine the fatty acid profile. Fatty acids were transesterified according to the Domínguez et al. (2015) procedure: $4 \mathrm{~mL}$ of a sodium methoxide $(2 \%)$ solution were added to the fat, vortexed every $5 \mathrm{~min}$ during $15 \mathrm{~min}$ at room temperature, followed by $4 \mathrm{~mL}$ of a $\mathrm{H}_{2} \mathrm{SO}_{4}$ solution (in methanol at 33\%), vortexed for a few seconds and vortexed again before adding $2 \mathrm{~mL}$ of distilled water. The organic phase (containing fatty acids methyl esters) was extracted with $2.5 \mathrm{~mL}$ of hexane.

The separation and quantification of FAMEs were carried out using a gas chromatograph, GC-Agilent 6890N (Agilent Technologies Spain, S.L., Madrid, Spain) equipped with a flame ionization detector and an automatic sample injector HP 7683, along with a Supelco SPTM-2560 fused silica capillary column $(100 \mathrm{~m}, 0.25 \mathrm{~mm}$ i.d., $0.2 \mu \mathrm{m}$ film thickness, SupelcoInc, Bellafonte, PA, USA). Chromatographic conditions were as follows: initial oven temperature of $120^{\circ} \mathrm{C}$ (held for $5 \mathrm{~min}$ ), first ramp at $5^{\circ} \mathrm{C} \cdot \mathrm{min}^{-1}$ to $200{ }^{\circ} \mathrm{C}$ (held for $2 \mathrm{~min}$ ) and second ramp at $1{ }^{\circ} \mathrm{C} \cdot \mathrm{min}^{-1}$ to a final temperature of $230^{\circ} \mathrm{C}$ (held for $3 \mathrm{~min}$ ). The injector and detector were maintained at 260 and $280{ }^{\circ} \mathrm{C}$, respectively. Helium was used as carrier gas at a constant flow-rate of $1.1 \mathrm{~mL} \cdot \mathrm{min}^{-1}$, with the column head pressure set at 35.56 psi. $1 \mu \mathrm{L}$ of solution was injected in split mode $(1: 50)$. Non adecanoic acid $(\mathrm{C} 19: 0)$ at $0.3 \mathrm{mg} \cdot \mathrm{mL}^{-1}$ was used as internal standard and added to the samples prior to methylation. Individual FAMEs were identified by comparing their retention times with those of authentic standards (Supelco 37 component FAME Mix) and the results were expressed as $\mathrm{g} \cdot 100 \mathrm{~g}^{-1}$ of total fatty acids. In addition, nutritional indices were calculated; atherogenic index (AI) and thrombogenic index (TI) were calculated according to Ulbricht and Sauthgate (1991):

$$
\begin{aligned}
\mathrm{AI}= & {\left[\mathrm{C} 12: 0+\left(4^{*} \mathrm{C} 14: 0\right)+\mathrm{C} 16: 0\right] / } \\
& {[(\Sigma \mathrm{PUFA})+(\Sigma \mathrm{MUFA})] ; } \\
\mathrm{TI}= & {[\mathrm{C} 14: 0+\mathrm{C} 16: 0+\mathrm{C} 18: 0] /\left[\left(0.5^{*} \Sigma \mathrm{MUFA}\right)+\right.} \\
& \left.\left(0.5^{*} n-6\right)+\left(3^{*} n-3\right)+(n-3 / n-6)\right] ;
\end{aligned}
$$

while the hypocholesterolemic / Hypercholesterolemic ratio $(\mathrm{h} / \mathrm{H})$ was calculated according to Fernández et al. (2007):

$\mathrm{h} / \mathrm{H}=[($ sum of $\mathrm{C} 18: 1 \mathrm{n} 9 \mathrm{c}, \mathrm{C} 18: 1 \mathrm{n} 7 \mathrm{c}, \mathrm{C} 18: 2 \mathrm{n} 6 \mathrm{c}$, C18:3n6, C18:3n3, C20:3n6, C20:4n6, C20:5n3, $\mathrm{C} 22: 4 \mathrm{n} 6, \mathrm{C} 22: 5 \mathrm{n} 3$ and $\mathrm{C} 22: 6 \mathrm{n} 3$ )/ (sum of $\mathrm{C} 14: 0$ and C16:0)]

\subsection{Statistical analysis}

A total of 30 pâtés (five pâtés for each batch $\times$ three batches $\times$ two replicates) were analyzed for different parameters. The effects of pork fat replacement by olive oil on chemical composition, color parameters, texture traits and fatty acid profile were examined using a mixed-model ANOVA, where these parameters were set as dependent variables, the pork fat replacement by olive oil as a fixed effect, and the replicate as a random effect. The pairwise differences between least-square means were evaluated by Duncan's method. Differences were considered significant if $P<0.05$. The values were given in terms of mean values and standard error (SEM). All analyses were conducted using the IBM SPSS Statistics 19.0 program (IBM Corp., 2010) software package.

\section{RESULTS AND DISCUSSION}

\subsection{Physico-chemical parameters}

Table 2 shows the effect of pork back fat replacement by olive oil on the $\mathrm{pH}$ and chemical composition of pâté. $\mathrm{pH}$ was significantly affected $(P<0.05)$ by fat replacement with olive oil between batches with $50 \%$ and $100 \%$ fat replacement, although none of them was significantly different regarding

\begin{tabular}{|c|c|c|c|c|c|}
\hline & \multicolumn{5}{|c|}{ Fat replacement } \\
\hline & $0 \%$ & $50 \%$ & $100 \%$ & SEM & Sig. \\
\hline $\mathrm{pH}$ & $6.10^{\mathrm{ab}}$ & $6.09^{\mathrm{a}}$ & $6.13^{\mathrm{b}}$ & 0.005 & * \\
\hline \multicolumn{6}{|c|}{ Chemical composition $\left(g \cdot 100 g^{-1}\right)$} \\
\hline Moisture & 52.46 & 52.51 & 51.50 & 0.284 & n.s. \\
\hline Fat & 18.23 & 18.41 & 19.63 & 0.354 & n.s. \\
\hline Protein & 24.87 & 24.53 & 24.30 & 0.102 & n.s. \\
\hline \multicolumn{6}{|c|}{ Color parameters } \\
\hline $\mathrm{L}^{*}$ & 57.70 & 56.66 & 55.88 & 0.474 & n.s. \\
\hline$a^{*}$ & 7.05 & 6.19 & 6.14 & 0.180 & n.s. \\
\hline$b^{*}$ & $19.43^{\mathrm{a}}$ & $20.18^{\mathrm{ab}}$ & $21.15^{\mathrm{b}}$ & 0.237 & $* *$ \\
\hline
\end{tabular}
the control batch. Apparently, statistical analyses

TABLE 2. Effect of olive oil amount on $\mathrm{pH}$ values, chemical composition and color parameters of pâté

${ }^{\mathrm{a}-\mathrm{b}}$ Mean values in the same row (corresponding to the same parameter) not followed by a common letter differ significantly $(P<0.05)$; Sig: significance: $* *(P<0.01), *(P<0.05)$, n.s. (not significant); SEM: standard error of the mean 
of results might seem conflicting. Nevertheless, it should be taken into account that although the $\mathrm{pH}$ values in the control batch are a bit higher than in the $50 \%$ fat replacement batch, the total fat replacement batch showed a more marked difference with respect to the above batches. Therefore it may be said that the back fat replacement in pâté affected $\mathrm{pH}$ values. Severini et al. (2003) did not find significant differences among batches in the partial substitution of pork back fat with extra-virgin olive oil in the elaboration of salami.

On the other hand, pork fat replacement by olive oil in the manufacture of pâté did not show significant differences in moisture, fat or protein among batches. These results are in agreement with those found by Rodríguez-Carpena et al. (2011), who partially replaced back fat by three vegetable oils in porcine burger patties. In contrast, Martin et al. (2008) reported different results during the formulation of liver pâté with fat replacement by olive and linoleic acid enriched oil. They observed significant differences $(P<0.05)$ between the control batch and oil enriched pâtés in moisture, fat and protein contents. They found that the control batch showed higher moisture and protein contents and a lower level of fat. This could be due to the lower lipid content of pork back fat (93\% approximately) compared to olive oil or oil rich in linoleic acid, since pork back fat also contains protein and water (approximately $1 \%$ and $5 \%$, respectively) (Ockerman, 1989). An additional reason given by authors for explaining the different composition of the control batch might be the cooking of pork back fat in water prior to preparation of the batter which led to a small loss in fat.

Morales-Irigoyen et al. (2012) found an increment in moisture content as more fat was replaced by emulsified canola oil in the manufacture of pork liver pâté. According to Morales-Irigoyen et al. (2012) this might be due to the water content in the emulsified oil used for fat replacement, joined to sodium caseinate to enhance moisture retention in meat batters and xanthan gum to improve water holding capacity and yield in low fat meat batters (Foegeding and Ramsey, 1986).

In terms of total fat content, no significant difference were found among the formulations. It is reported in the literature that the replacement of animal fat with oil does not have an influence on the total fat content (Muguerza et al., 2002).

It has been reported in the bibliography that liver pâté formulations (Martín et al., 2008; MoralesIrigoyen et al., 2012) or even a meat product made of pork liver (Sánchez-Zapata et al., 2013) has a higher fat percentage than we employed in the elaboration of our pâté. Thus, around $17.5 \%$ on average of fat reduction among all batches was obtained in comparison with the liver product manufactured by Sánchez-Zapata et al. (2013) or even to exceed
$30 \%$ with liver pâté from Morales-Irigoyen et al. (2012). This low fat percentage makes our pâté healthier, since dietary fat, mainly saturated fat, it is an important factor contributing to the development of cardiovascular disease, cancer, diabetes and other degenerative diseases. In addition, dietary fat is often blamed as the major source of excess energy strongly linked to the increasing epidemic proportion of obesity (Chang and Chow, 2008). This fat reduction increases the lean ratio and, as a consequence, the protein proportion, which favors an increased intake of essential amino acids in the diet. The protein ratio reached values per $100 \mathrm{~g}$ of product of $24.87 \mathrm{~g}, 24.53 \mathrm{~g}$ and $24.30 \mathrm{~g}$ corresponding to the control batch, $50 \%$ and $100 \%$ fat replacement batches, respectively. These protein contents are higher than those obtained by Sánchez-Zapata et al. (2013) who noticed values of $10 \mathrm{~g} \cdot 100 \mathrm{~g}^{-1}$ of product on average among all batches assayed. A protein increment in the final product means the presence of more essential amino acids, making it a more nutritive product.

\subsection{Color parameters}

Table 2 shows the effect of pork back fat replacement by olive oil on the color parameters of pâté. The color parameters did not show significant differences among groups, except when pork fat was completely substituted by olive oil, where the control batch presented $a b^{*}$ value significantly lower $(P<0.01)$ than the $100 \%$ replacement batch. Therefore, we might conclude that the $b^{*}$ parameter was the only one significantly affected by fat replacement by olive oil in pâté. These outcomes are in disagreement with those reported by Morales-Irigoyen et al. (2012) as to lightness and redness, since they found significant changes $(P<0.05)$ in these parameters when fat was substituted by emulsified canola oil. However, our findings in yellowness are similar to those reported by them. Choi et al. (2009) also reported significantly different results $(P<0.05)$ among all batches in the partial replacement of animal fat with various vegetable oils emulsified with dietary fiber extracted from rice bran in the manufacture of a cooked batter made of pork ham. Nevertheless, in this case, lightness and yellowness showed a different behavior regarding values observed by Morales-Irigoyen et al. (2012), which increased and decreased respectively. The differences in color parameters may be due to differences between the oils (canola vs. olive oil) used in each study. In addition, Morales-Irigoyen et al. (2012) emulsified oil (oil + water + caseinate) before adding the pâté while we incorporated the oil directly, which may also affect color parameters.

According to Choi et al. (2009) the replacement of fat could compensate for color changes in emulsified meat products, where animal fat replaced by 
vegetable oil increases lightness and yellowness but decreases redness. The distribution of the oil phase into the protein matrix during the chopping process allows for color differences, since fat particle area is higher when vegetable oils are present in the formulation because they seem to be evenly dispersed and are better distributed than the animal fat tissue (Youssef and Barbut, 2010).

\subsection{Texture parameters}

The effect of the pork backfat replacement by olive oil on the texture parameters of pâté is presented in Table 3. The replacement of fat by olive oil resulted in pâtés with different textural properties. As expected, emulsified oil presented a softer texture than pork back fat, and therefore, it obtained a significant hardness reduction $(P<0.001)$ when fat was replaced with olive oil, and hence, the force to compress the pâté samples, related to maximum peak force and the work necessary to compress it, was higher in the control group. The data obtained for hardness are in agreement with those observed by Martín et al. (2008), who found a great difference in consistency between the control pâté and fat reduced pâtés with oil enriched with linoleic acid and olive oil. Thus, the experimental batches showed a softer consistency than the control batch, formulated in the traditional way with pork fat as the only added fat source. The authors concluded that the main factor responsible of the observed soft consistency in all batches is due to the decrease in saturated fats and the increase in unsaturated fats when pork back fat was replaced by oils. On the other hand, they noted that it would be possible that the adipocyte structure of back fat tissue remains intact after the manufacture. According to them, this might contribute to the higher consistency of the control batch, since the fat would remain inside the adipocytes. Morales-Irigoyen et al. (2012) also reported lower hardness values $(P<0.05)$ in batches with fat replacement, in this case by emulsified

TABLE 3. Effect of olive oil amount on texture parameters of pâté

\begin{tabular}{lccccc}
\hline & \multicolumn{5}{c}{ Fat replacement } \\
\cline { 2 - 5 } TPA traits & $\mathbf{0 \%}$ & $\mathbf{5 0} \%$ & $\mathbf{1 0 0} \%$ & SEM & Sig. \\
\hline Hardness (N) & $4.50^{\mathrm{b}}$ & $3.33^{\mathrm{a}}$ & $3.33^{\mathrm{a}}$ & 0.15 & $* * *$ \\
Elasticity (mm) & 1.01 & 1.00 & 0.99 & 0.006 & n.s. \\
Cohesiveness & $0.47^{\mathrm{b}}$ & $0.44^{\mathrm{a}}$ & $0.44^{\mathrm{a}}$ & 0.005 & $*$ \\
Gumminess (N) & $2.15^{\mathrm{b}}$ & $1.47^{\mathrm{a}}$ & $1.37^{\mathrm{a}}$ & 0.07 & $* * *$ \\
Chewiness (N) & $2.12^{\mathrm{b}}$ & $1.44^{\mathrm{a}}$ & $1.33^{\mathrm{a}}$ & 0.06 & $* * *$ \\
\hline
\end{tabular}

${ }^{\mathrm{a}-\mathrm{b}}$ Mean values in the same row (corresponding to the same parameter) not followed by a common letter differ significantly $(P<0.05)$; Sig: significance: *** $(P<0.001), *(P<0.05)$, n.s. (not significant); SEM: standard error of the mean canola oil, in the elaboration of pork liver pâté, which led to a more spreadable texture.

As in the hardness parameter, the fat replacement caused a significant reduction $(P<0.001)$ in gumminess and chewiness, also showing a progressive decline as fat was replaced by olive oil. Gumminess and chewiness are parameters directly dependent of hardness, thus, similar results were expected. In a like manner, cohesiveness showed a higher value $(P<0.05)$ in the control pâté than in the rest, but it did not show a progressive decrease as fat was replaced by olive oil as in the case of gumminess and chewiness. This outcome is in disagreement with those reported by Asuming-Bediako et al. (2014) who did not find any significant difference between UK-style sausages manufactured with back fat and with total or partial replacement by rapeseed oil.

\subsection{Fatty acids profile, cholesterol and tocopherol content and nutritional indices}

Table 4 shows the effect of the pork back fat replacement by olive oil on the fatty acid profile, nutritional indices, cholesterol and $\alpha$-tocopherol content of pâté. The most abundant fatty acids in all the samples were monounsaturated fatty acids (MUFA), followed by saturated fatty acids (SFA) and polyunsaturated fatty acids (PUFA). In the pâté samples, oleic acid $(\mathrm{C} 18: 1 \mathrm{n} 9 \mathrm{c})$ was the most abundant fatty acid, representing between 42.92 and 56.92 $\mathrm{g} \cdot 100 \mathrm{~g}^{-1}$ of total fatty acids, followed by palmitic (C16:0; 20.61-17.87 g.100 g-1 of FAME), linolenic (C18:2n6c; 14.14-9.80 g.100 $\mathrm{g}^{-1}$ of FAME) and stearic acid (C18:0; 10.5-5.93 g.100 g $\mathrm{g}^{-1}$ of FAME). These four fatty acids comprise around $90 \%$ of the total fatty acids analyzed in the pâté. Our results are consistent with reports on the fatty acid profile of similar meat products formulated with pork meat and back fat and/or with replacement of this back fat by olive oil (Martín et al., 2008; RodríguezCarpena et al., 2012).

As expected, the pork fat replacement with olive oil had a significant effect on the fatty acid composition of the pâté. As compared with the control batch, the pâté formulated with olive oil (both, 50 and $100 \%$ replacement) contained higher $(P<0.001)$ amounts of MUFA (49.84, 55.28 and $63.21 \mathrm{~g} \cdot 100 \mathrm{~g}^{-1}$ of FAME in control, $50 \%$ and $100 \%$ batches, respectively). This fact is related to the high content of $\mathrm{C} 18 \mathrm{in} 9 \mathrm{c}(69.22 \%$; data not shown) in the olive oil used in this study. Diets rich in MUFA have been associated with positive health benefits (López-Miranda et al., 2006). A significant increase in MUFA in modified pâtés was compensated with a significant decrease in the content of both SFA and PUFA. This fact agrees with the results reported by Martín et al.(2008) and Rodríguez-Carpena et al. (2012) who also found an increase in MUFA and decrease in SFA 
TABLE 4. Effect of olive oil amount on fatty acid profile, nutritional indices, cholesterol and $\alpha$-tocopherol content of pâté

\begin{tabular}{|c|c|c|c|c|c|}
\hline \multirow[b]{2}{*}{ Fatty acids } & \multicolumn{5}{|c|}{ Fat replacement } \\
\hline & $0 \%$ & $50 \%$ & $100 \%$ & SEM & Sig. \\
\hline C10:0 & $0.04^{\mathrm{c}}$ & $0.02^{\mathrm{b}}$ & $0.00^{\mathrm{a}}$ & 0.005 & $* * *$ \\
\hline $\mathrm{C} 12: 0$ & $0.06^{\mathrm{c}}$ & $0.05^{\mathrm{b}}$ & $0.00^{\mathrm{a}}$ & 0.005 & $* * *$ \\
\hline $\mathrm{C} 14: 0$ & $1.32^{\mathrm{c}}$ & $1.02^{\mathrm{b}}$ & $0.66^{\mathrm{a}}$ & 0.053 & $* * *$ \\
\hline $\mathrm{C} 14: 1$ & 0.05 & 0.04 & 0.03 & 0.005 & n.s. \\
\hline $\mathrm{C} 16: 0$ & $20.61^{\mathrm{c}}$ & $19.38^{\mathrm{b}}$ & $17.87^{\mathrm{a}}$ & 0.237 & $* * *$ \\
\hline $\mathrm{C} 16: \ln 7$ & $2.01^{\mathrm{b}}$ & $1.97^{\mathrm{b}}$ & $1.86^{\mathrm{a}}$ & 0.019 & $* *$ \\
\hline $\mathrm{C} 17: 0$ & $0.26^{\mathrm{c}}$ & $0.22^{\mathrm{b}}$ & $0.18^{\mathrm{a}}$ & 0.007 & $* * *$ \\
\hline $\mathrm{C} 17: 1$ & 0.25 & 0.25 & 0.26 & 0.002 & n.s. \\
\hline C18:0 & $10.50^{\mathrm{c}}$ & $8.58^{\mathrm{b}}$ & $5.93^{\mathrm{a}}$ & 0.369 & $* * *$ \\
\hline $\mathrm{C} 18: \ln 9 \mathrm{t}$ & $0.30^{\mathrm{c}}$ & $0.25^{\mathrm{b}}$ & $0.16^{\mathrm{a}}$ & 0.012 & $* * *$ \\
\hline $\mathrm{C} 18: \ln 9 \mathrm{c}$ & $42.92^{\mathrm{a}}$ & $48.63^{\mathrm{b}}$ & $56.92^{\mathrm{c}}$ & 1.148 & $* * *$ \\
\hline $\mathrm{C} 18: \ln 7 \mathrm{c}$ & $3.20^{\mathrm{a}}$ & $3.28^{\mathrm{b}}$ & $3.41^{\mathrm{c}}$ & 0.022 & $* * *$ \\
\hline $\mathrm{C} 18: 2 \mathrm{n} 6 \mathrm{c}$ & $14.14^{\mathrm{b}}$ & $12.63^{\mathrm{b}}$ & $9.80^{\mathrm{a}}$ & 0.493 & $* * *$ \\
\hline C20:0 & $0.21^{\mathrm{a}}$ & $0.26^{\mathrm{b}}$ & $0.33^{\mathrm{c}}$ & 0.010 & $* * *$ \\
\hline C20:1n9 & $1.11^{\mathrm{c}}$ & $0.86^{\mathrm{b}}$ & $0.57^{\mathrm{a}}$ & 0.044 & $* * *$ \\
\hline $\mathrm{C} 18: 3 \mathrm{n} 3$ & $0.98^{\mathrm{c}}$ & $0.85^{\mathrm{b}}$ & $0.69^{\mathrm{a}}$ & 0.024 & $* * *$ \\
\hline $\mathrm{C} 20: 2 \mathrm{n} 6$ & $0.86^{\mathrm{c}}$ & $0.57^{\mathrm{b}}$ & $0.22^{\mathrm{a}}$ & 0.052 & $* * *$ \\
\hline C20:3n6 & $0.11^{\mathrm{c}}$ & $0.08^{\mathrm{b}}$ & $0.04^{\mathrm{a}}$ & 0.006 & $* * *$ \\
\hline $\mathrm{C} 20: 3 \mathrm{n} 3$ & $0.22^{\mathrm{c}}$ & $0.14^{\mathrm{b}}$ & $0.03^{\mathrm{a}}$ & 0.015 & $* * *$ \\
\hline C20:4n6 & $0.66^{\mathrm{b}}$ & $0.58^{\mathrm{ab}}$ & $0.50^{\mathrm{a}}$ & 0.023 & $*$ \\
\hline $\mathrm{C} 23: 0$ & $0.02^{\mathrm{a}}$ & $0.17^{\mathrm{b}}$ & $0.36^{\mathrm{c}}$ & 0.028 & $* * *$ \\
\hline $\mathrm{C} 22: 5 \mathrm{n} 3$ & $0.14^{\mathrm{c}}$ & $0.11^{\mathrm{b}}$ & $0.07^{\mathrm{a}}$ & 0.006 & $* * *$ \\
\hline SFA & $33.05^{\mathrm{c}}$ & $29.74^{\mathrm{b}}$ & $25.43^{\mathrm{a}}$ & 0.626 & $* * *$ \\
\hline MUFA & $49.84^{\mathrm{a}}$ & $55.28^{\mathrm{b}}$ & $63.21^{\mathrm{c}}$ & 1.102 & $* * *$ \\
\hline PUFA & $17.12^{\mathrm{c}}$ & $14.97^{\mathrm{b}}$ & $11.36^{\mathrm{a}}$ & 0.572 & $* * *$ \\
\hline$\sum \mathrm{n} 3$ & $1.34^{\mathrm{c}}$ & $1.10^{\mathrm{b}}$ & $0.80^{\mathrm{a}}$ & 0.044 & $* * *$ \\
\hline$\sum \mathrm{n} 6$ & $15.78^{\mathrm{c}}$ & $13.87^{\mathrm{b}}$ & $10.56^{\mathrm{a}}$ & 0.541 & $* * *$ \\
\hline$\sum \mathrm{n} 6 / \sum \mathrm{n} 3$ & 11.69 & 12.70 & 13.54 & 0.468 & n.s. \\
\hline $\mathrm{P} / \mathrm{S}$ & 0.52 & 0.50 & 0.45 & 0.015 & n.s. \\
\hline AI & $0.40^{\mathrm{c}}$ & $0.33^{\mathrm{b}}$ & $0.28^{\mathrm{a}}$ & 0.009 & $* * *$ \\
\hline $\mathrm{TI}$ & $0.89^{\mathrm{c}}$ & $0.75^{\mathrm{b}}$ & $0.62^{\mathrm{a}}$ & 0.021 & $* * *$ \\
\hline $\mathrm{h} / \mathrm{H}$ & $2.78^{\mathrm{a}}$ & $3.31^{\mathrm{b}}$ & $3.87^{\mathrm{c}}$ & 0.086 & $* * *$ \\
\hline Nutritive value & $2.55^{\mathrm{a}}$ & $3.00^{\mathrm{b}}$ & $3.52^{\mathrm{c}}$ & 0.075 & $* * *$ \\
\hline$\alpha$-Tocopherol $\left(\mu \mathrm{g} \cdot \mathrm{g}^{-1}\right)$ & $9.22^{\mathrm{a}}$ & $24.80^{\mathrm{b}}$ & $51.66^{\mathrm{c}}$ & 3.666 & $* * *$ \\
\hline Cholesterol $\left(\mathrm{mg} \cdot 100 \mathrm{~g}^{-1}\right)$ & $35.20^{\mathrm{c}}$ & $30.85^{\mathrm{b}}$ & $26.50^{\mathrm{a}}$ & 2.899 & $* * *$ \\
\hline
\end{tabular}

a-c Mean values in the same row (corresponding to the same parameter) not followed by a common letter differ significantly $(P<0.05)$; Sig: $\quad$ significance: $\quad * * *(P<0.001), \quad * *(P<0.01)$, $*(P<0.05)$, n.s. (not significant); SEM: standard error of the mean; SFA: saturated fatty acids; MUFA: monounsaturated fatty acids; PUFA: polyunsaturated fatty acids; P/S: PUFA/ SFA ratio; AI: atherogenic index $=[\mathrm{C} 12: 0+(4 * \mathrm{C} 14: 0)+\mathrm{C} 16: 0] /$ [( $\mathrm{PUFA})+(\Sigma \mathrm{MUFA})]$ (Ulbricht and Sauthgate, 1991); TI: thrombogenic index $=[\mathrm{C} 14: 0+\mathrm{C} 16: 0+\mathrm{C} 18: 0] /[(0.5 * \Sigma \mathrm{MUFA})+$ $\left.\left(0.5^{*} n-6\right)+\left(3^{*} n-3\right)+(n-3 / n-6)\right]$ (Ulbricht and Sauthgate, 1991); h/H the hypocholesterolemic / Hypercholesterolemic ratio $=[$ (sum of C18:1n9c, C18:1n7c, C18:2n6c, C18:3n6, C18:3n3, C20:3n6, $\mathrm{C} 20: 4 \mathrm{n} 6, \mathrm{C} 20: 5 \mathrm{n} 3, \mathrm{C} 22: 4 \mathrm{n} 6, \mathrm{C} 22: 5 \mathrm{n} 3$ and $\mathrm{C} 22: 6 \mathrm{n} 3) /(\mathrm{sum}$ of C14:0 and C16:0)] (Fernández et al., 2007); Nutritive value = $[(\mathrm{C} 18: 0+\mathrm{C} 18: \ln 9 \mathrm{c}) / \mathrm{C} 16: 0]$ and PUFA in liver pâté and burger patties with pork fat replacement by olive oil.

As previously mentioned, the control batch had higher contents $(P<0.001)$ of SFA $(33.05 \mathrm{~g} / 100 \mathrm{~g}$ of FAME) than the samples formulated with olive oil (29.74 and $25.43 \mathrm{~g} \cdot 100 \mathrm{~g}^{-1}$ of FAME in 50 and $100 \%$ batches, respectively). It is well known that not all SFA have the same hypercholesterolaemic effect. While C18:0 is neutral, myristic acid (C14:0) and C16:0 produce the greatest atherogenic effects $(\mathrm{Hu}$ et al., 2011). In our study, when the pork back fat was replaced by olive oil, the contents of C14:0 and C16:0 decreased from $21.93 \mathrm{~g} \cdot 100 \mathrm{~g}^{-1}$ of FAME in the control batch to $20.40 \mathrm{~g} \cdot 100 \mathrm{~g} \mathrm{~g}^{-1}$ of FAME in the $50 \%$ batch and to $18.53 \mathrm{~g} \cdot 100 \mathrm{~g}^{-}$of FAME in the $100 \%$ batch. The incorporation of olive oil also caused considerable changes in the PUFA content. The content of all individual and total PUFA decreased with back fat replacement. The major changes were obtained in C18:2n6c. The amount of this fatty acid decreased from $14.14 \mathrm{~g} \cdot 100 \mathrm{~g}^{-1}$ of FAME in the control batch to 12.63 and $9.80 \mathrm{~g} \cdot 100 \mathrm{~g}^{-1}$ of FAME in the 50 and $100 \%$ batches, respectively.

As mentioned above, fatty acid composition is of crucial importance for determining the properties and health benefits of a food, particularly for cardiovascular health. The replacement of SFA by unsaturated ones (cis-MUFA and cis-PUFA) helps to keep LDL-cholesterol at normal concentrations in the blood (EFSA, 2011) and this health claim can be used for foods in which unsaturated fatty acids account for at least $70 \%$ of the total fatty acids and represents at least $20 \%$ of the energy intake (EU Reg. 432/2012). In our case, MUFA and PUFA together accounted for 66,70 and $75 \%$ of total fatty acids from the control, 50 and $100 \%$ back fat replacement batches, respectively. In addition, the unsaturated fatty acids accounted for 41 and $45 \%$ of the total energy intake (data not shown) in the samples with 50 and $100 \%$ replacement of back fat, respectively. Therefore, according to EFSA (2011) the samples from 50 and $100 \%$ replacement of back fat with olive oil would allow us to maintain LDL-cholesterol at normal concentrations, and this health claim could be used for advertising purposes, which also increases the market competitiveness of these products.

On the other hand, the $\mathrm{P} / \mathrm{S}$ ratio and $\mathrm{n}-6 / \mathrm{n}-3$ PUFA ratio did not show differences among batches. Nutritional guidelines recommend a $\mathrm{P} / \mathrm{S}$ ratio above 0.4 (UK Department of Health, 1994) although the high proportion of PUFA in itself is not necessarily healthy if it is not balanced in relation to the $n-6 /$ n-3 ratio, which should not exceed 4 (Simopoulos, 2004). Excessive amounts of n-6 PUFA and very high n-6/n-3 PUFA ratios promote several kinds of pathogenesis, including cardiovascular disease, cancer and inflammatory and autoimmune diseases, whereas increased levels of n-3 PUFA (and 
low n-6/n-3 PUFA ratios) exert suppressive effects (Simopoulos, 2004). In our study, the value of the $\mathrm{P} / \mathrm{S}$ ratio presented similar values to those recommended (between 0.45 and 0.52 ), however, the $\mathrm{n}-6 / \mathrm{n}-3$ ratio exceeded the values recommended by nutritional organizations. In contrast, the atherogenic (AI) and thrombogenic (TI) indexes decreased $(P<0.001)$ as back fat was replaced by olive oil $(0.40$ for AI and 0.89 for TI in the control batch; 0.33 for AI and 0.75 for TI in the $50 \%$ batch; 0.28 for AI and 0.62 for TI in the $100 \%$ batch). The hypocholesterolemic/ hypercholesterolemic ratio was higher in reformulated pâté than in the control samples (2.78 in the control samples vs. 3.31 and 3.87 in 50 and $100 \%$ batches). In addition, the nutritive value also increased as olive oil was included in the pâté. Nutritional improvements with the replacement of animal fat for vegetable oils were also observed by other authors (Delgado-Pando et al., 2011; Rodríguez-Carpena et al., 2012) who reported lower AI and TI in reformulated meat products than in products with pork back fat.

Finally, the inclusion of olive oil considerably reduced the cholesterol content, while it increased the $\alpha$-tocopherol content. It is well known that olive oil has a high content of $\alpha$-tocopherol (between 108 and $386 \mathrm{mg} \cdot \mathrm{kg}^{-1}$ ) (Caporaso et al., 2015). Therefore, the use of olive oil in the formulation of pâté increased the content of tocopherol from $9.22 \mu \mathrm{g} \cdot \mathrm{g}^{-1}$ in the control batch to 24.80 and $51.66 \mu \mathrm{g} \cdot \mathrm{g}^{-1}$ in the 50 and $100 \%$ batches, respectively. The high content of tocopherol in reformulated batches had health benefits. According to EFSA (2010), olive oil polyphenols contribute to the protection of blood lipids from oxidative stress. In addition, the use of cholesterol-free fat (olive oil) to replace the pork back fat resulted in a decrease in the total cholesterol content in the final product. In this sense, the control batches presented higher $(P<0.001)$ contents of cholesterol than the reformulated pâtés $\left(35.20 \mathrm{mg} \cdot 100 \mathrm{~g}^{-1}\right.$ in the control batch vs. 30.85 and $26.50 \mathrm{mg} \cdot 100 \mathrm{~g}^{-1}$ in the 50 and $100 \%$ batches, respectively). These amounts were lower than those reported for other meat products such as chicken pâté, with values between 59 and $62 \mathrm{mg} \cdot 100 \mathrm{~g}^{-1}$ (Polak et al., 2011) and pork liver pâté, with values ranging between 77 and 102 $\mathrm{mg} \cdot 100 \mathrm{~g}^{-1}$ (Echarte et al., 2004). Our findings agree with the results reported by Choi et al. (2010), who concluded that the cholesterol content decreased with the replacement of animal fat by vegetable oils.

\section{CONCLUSIONS}

The replacement of pork back fat by olive oil allows us to obtain a new pâté with higher nutritional value than traditional pâtés. The replacement of $100 \%$ of back fat by olive oil presented the best nutritional values. Olive oil provides pâté with high levels of C18:1n9c and MUFA, natural antioxidants such as $\alpha$-tocopherol and reduces cholesterol levels without considerably affecting the physico-chemical, color or texture parameters. Therefore, the use of olive oil allows us to obtain a healthier product. However an exhaustive study on the effect the substitution of fat has on the sensory characteristics of the product is necessary.

\section{ACKNOWLEDGEMENTS}

The authors are grateful to The Xunta de Galicia (The Regional Government) (Project FEADER 2012/85) for financial support.

\section{REFERENCES}

Asuming-Bediako N, Jaspal MH, Hallett K, Bayntun J, Baker A, Sheard PR. 2014. Effects of replacing pork backfat with emulsified vegetable oil on fatty acid composition and quality of UK-style sausages. Meat Sci. 96, 187-194. http://dx.doi.org/10.1016/j.meatsci.2013.06.031.

Bligh EG, Dyer WJ. 1959. A rapid method of total lipid extraction and purification. Can. J. Biochem. Phys. 37, 911-917. http://dx.doi.org/10.1139/o59-099.

Bloukas JG, Paneras ED, Fournitzis GC. 1997. Effect of replacing pork backfat with olive oil on processing and quality characteristics of fermented sausages. Meat Sci. 45 , 133-144. http://dx.doi.org/10.1016/S0309-1740(96)00113-1.

Caporaso N, Savarese M, Paduano A, Guidone G, De Marco E, Sacchi R. 2015. Nutritional quality assessment of extra virgin olive oil from the Italian retail market: Do natural antioxidants satisfy EFSA health claims?. J. Food Compos. Anal. 40, 154-162. http://dx.doi.org/10.1016/j. jfca.2014.12.012.

Chang SJ, Chow CKJ. 2008. Consumption of fatty acids, in Chow CK (Ed.) Fatty acids in foods and their health application. 3rd edn. Boca Raton, FL: CRC Press, 545-559.

Choi YS, Choi JH, Han DJ, Kim HY, Lee MA, Jeong JY, Chung HJ, Kim CJ. 2010. Effects of replacing pork back fat with vegetable oils and rice bran fiber on the quality of reducedfat frankfurters. Meat Sci. 84, 557-563. http://dx.doi. org/10.1016/j.meatsci.2009.10.012.

Choi YS, Choi JH, Han DJ, Kim HY, Lee MA, Kim HW, Jeong JY, Kim CJ. 2009. Characteristics of low-fat meat emulsion systems with pork fat replaced by vegetable oils and rice bran fiber. Meat Sci. 82, 266-271. http://dx.doi. org/10.1016/j.meatsci.2009.01.019.

Delgado-Pando G, Cofrades S, Rodríguez-Salas L, JiménezColmenero F. 2011. A healthier oil combination and konjac gel as functional ingredients in low-fat pork liver pâté. Meat Sci. 88, 241-248. http://dx.doi.org/10.1016/j. meatsci.2010.12.028.

Domínguez R, Borrajo P, Lorenzo JM. 2015. The effect of cooking methods on nutritional value of foal meat. J. Food Compos. Anal. 43, 61-67. http://dx.doi.org/10.1016/j. jfca.2015.04.007.

Echarte M, Conchillo A, Ansorena D, Astiasarán I. 2004. Evaluation of the nutritional aspects and cholesterol oxidation products of pork liver and fish pates. Food Chem. 86, 47-53. http://dx.doi.org/10.1016/j.foodchem. 2003.08.027.

EFSA. 2010. Scientific Opinion on the substantiation of health claims related to vitamin E and protection of DNA, proteins and lipids from oxidative damage (ID 160, 162, 1947), maintenance of the normal function of the immune system (ID 161, 163), maintenance of normal bone (ID 164), maintenance of normal teeth (ID 164), maintenance of normal hair (ID 164), maintenance of normal skin (ID 164), maintenance of normal nails (ID 164), maintenance of normal cardiac function (ID 166), maintenance of normal vision by protection of the lens of the eye (ID 167), contribution to 
normal cognitive function (ID 182, 183), regener-ation of the reduced form of vitamin C (ID 203), maintenance of normal blood circulation (ID 216) and maintenance of normal a scalp (ID 2873) pursuant to Article 13(1) of Regulation (EC) No 1924/20061. EFSA J. 8, 1816.

EFSA. 2011. Scientific Opinion on the substantiation of health claims related to the replacement of mixtures of saturated fatty acids (SFAs) as present in foods or diets with mixtures of monounsaturated fatty acids (MUFAs) and/or mixtures of polyunsaturated fatty acids (PUFAs), and maintenance of normal blood LDL-cholesterol concentrations (ID 621, 1190, 1203, 2906, 2910, 3065) pursuant to Article 13(1) of Regulation (EC) No 1924/20061. EFSA J. 9, 2069.

EU Reg. No 432/2012 of 16 May 2012 establishing a list of permitted health claims made on foods, other than those referring to the reduction of disease risk and to children's development and health.

Fernández M, Ordoñez JA, Cambero I, Santos C, Pin C, de la Hoz L. 2007. Fatty acid composition of selected varieties of Spanish dry ham related to their nutritional implications. Food Chem. 101, 107-112. http://dx.doi.org/10.1016/j. foodchem.2006.01.006

Foegeding EA, Ramsey SR. 1986. Effect of Gums on LowFat Meat Batters. J. Food Sci. 51, 33-36. http://dx.doi. org/10.1111/j.1365-2621.1986.tb10829.x.

Hu FB, Manson JE, Willett WC. 2001. Types of dietary fat and risk of coronary heart disease: a critical review. J. Am. Coll Nutr. 20, 5-19. http://dx.doi.org/10.1080/07315724.2001.1 0719008 .

Huang CL, Sumpio BE. 2008. Olive oil, the Mediterranean diet, and cardiovascular health. J. Am. Coll Surgeons. 207, 407-416. http://dx.doi.org/10.1016/j.jamcollsurg.2008.02.018

IBM Corp. 2010. IBM SPSS statistics for Windows, version 19.0. New York, NY, USA: IBM Corp.

ISO 1973. Determination of total fat content, ISO 1443:1973 standard. International standards meat and meat products. Genève, Switzerland: International Organization for Standardization.

ISO 1978. Determination of nitrogen content, ISO 937:1978 standard. International standards meat and meat products. Genève, Switzerland: International Organization for Standardization.

ISO 1997. Determination of moisture content, ISO 1442:1997 standard. International standards meat and meat products. Genève, Switzerland: International Organization for Standardization.

Jiménez-Colmenero, F. 2007. Healthier lipid formulation approaches in meat-based functional foods. Technological options for replacement of meat fats by non-meat fats. Trends Food Sci. Tech. 18, 567-578. http://dx.doi. org/10.1016/j.tifs.2007.05.006

López-Miranda J, Pérez-Martínez P, Pérez-Jiménez F. 2006. Health benefits of monounsaturated fatty acids, in Williams C., \& Buttriss J. (Ed.) Improving the Fat Content of Foods Cambridge. Woodhead Publishing Limited, 71-106.

Lorenzo JM, Pateiro M. 2013. Influence of fat content on physico-chemical and oxidative stability of foal liver pâté. Meat Sci. 95, 330-335.http://dx.doi.org/10.1016/j.meatsci. 2013.04.045.

Lorenzo JM, Pateiro M, Fontán MCG, Carballo J. 2014. Effect of fat content on physical, microbial, lipid and protein changes during chill storage of foal liver pâté. Food Chem. 155, 57-63. http://dx.doi.org/10.1016/j.foodchem. 2014.01 .038

Martín D, Ruiz J, Kivikari R, Puolanne E. 2008. Partial replacement of pork fat by conjugated linoleic acid and/or olive oil in liver pâtés: Effect on physicochemical characteristics and oxidative stability. Meat Sci. 80, 496-504. http:// dx.doi.org/10.1016/j.meatsci.2008.01.014.

Martin D, Antequera T, Muriel E, Perez-Palacios T, Ruiz J. 2009. Liver pâté from pigs fed conjugated linoleic acid and monounsaturated fatty acids. Eur. Food Res. Technol. 228, 749-758. http://dx.doi.org/10.1007/s00217-008-0986-8.
Morales-Irigoyen EE, Severiano-Pérez P, Rodríguez-Huezo ME, Totosaus A. 2012. Textural, physicochemical and sensory properties compensation of fat replacing in pork liver pate incorporating emulsified canola oil. Food Sci. Technol. Int. 18, 413-421. http://dx.doi.org/10.1177/1082013211428218.

Muguerza E, Gimeno O, Ansorena D, Bloukas JG, Astiasarán I. 2001. Effect of replacing pork backfat with pre-emulsified olive oil on lipid fraction and sensory quality of Chorizo de Pamplona - a traditional Spanish fermented sausage. Meat Sci. 59, 251-258. http://dx.doi.org/10.1016/ S0309-1740(01)00075-4.

Muguerza E, Fista G, Ansorena D, Astiasaran I, Bloukas JG. 2002. Effect of fat level and partial replacement of pork backfat with olive oil on processing and quality characteristics of fermented sausages. Meat Sci. 61, 397-404. http:// dx.doi.org/10.1016/S0309-1740(01)00210-8.

Ockerman HW. 1989. Sausage and processed meat formulations. Ohio, USA: Van NostrandReinhold.

Polak T, Žlender B, Lušnic M, Gašperlin L. 2011. Effects of coenzyme Q 10, $\alpha$-tocopherol and ascorbic acid on oxidation of cholesterol in chicken liver pâté. LWT-Food Sci Technol. 44, 1052-1058. http://dx.doi.org/10.1016/j.lwt. 2010.10.010.

Reboredo-Rodríguez P, González-Barreiro C, Cancho-Grande B, Simal-Gándara J. 2014. Quality of extra virgin olive oils produced in an emerging olive growing area in northwestern Spain. Food Chem. 164, 418-426. http://dx.doi. org/10.1016/j.foodchem.2014.05.043.

Rodríguez-Carpena JG, Morcuende D, Estévez M. 2011. Partial Replacement of Pork Back-Fat by Vegetable Oils in Burger Patties: Effect on Oxidative Stability and Texture and Color Changes during Cooking and Chilled Storage. J. Food Sci. 76, C1025-C1031. http://dx.doi.org/ 10.1111/j.1750-3841.2011.02327.x.

Rodríguez-Carpena JG, Morcuende D, Estévez M. 2012. Avocado, sunflower and olive oils as replacers of pork back-fat in burger patties: Effect on lipid composition, oxidative stability and quality traits. Meat Sci. 90, 106-115. http://dx.doi.org/10.1016/j.meatsci.2011.06.007.

Salcedo-Sandoval L, Cofrades S, Ruiz-Capillas C, JiménezColmenero F. 2014. Effect of cooking method on the fatty acid content of reduced-fat and PUFA-enriched pork patties formulated with a konjac-based oil bulking system. Meat Sci. 98, 795-803. http://dx.doi.org/10.1016/j. meatsci.2014.07.034.

Sampaio GR, Castellucci CM, Silva MEMP, Torres EA. 2004. Effect of fat replacers on the nutritive value and acceptability of beef frankfurters. J. Food Compos. Anal. 17, 469-474. http://dx.doi.org/10.1016/j.jfca.2004.03.016.

Sánchez-Zapata E, Sayas-Barberá E, Pérez-Alvarez JA, Fernández-López J. 2013. The Effect of Replacing Water with Tiger Nut Milk (Horchata) Liquid Coproduct on the Physicochemical Properties and Oxidation (Haemopigments and Lipids) of a Cooked Pork Liver Meat Product. Food Technol. Biotech. 51, 422-428.

Severini C, De Pilli T, Baiano, A. 2003. Partial substitution of pork backfat with extra-virgin olive oil in 'salami'products: effects on chemical, physical and sensorial quality. Meat Sci. 64, 323-331. http://dx.doi.org/10.1016/ S0309-1740(02)00204-8.

Simopoulos AP. 2004. Omega-6/omega-3 essential fatty acid ratio and chronic diseases. Food Rev. Int. 20, 77-90. http:// dx.doi.org/10.1081/FRI-120028831.

UK Department of Health 1994. Nutritional aspects of cardiovascular disease. Report on health and social subject no. 46. London: Her Majesty's Stationery Office.

Ulbricht TLV, Southgate DAT. 1991. Coronary heart disease: Seven dietary factors. Lancet. 338, 985-992. http://dx.doi. org/10.1016/0140-6736(91)91846-M.

Youssef MK, Barbut S. 2010. Physicochemical effects of the lipid phase and protein level on meat emulsion stability, texture, and microstructure. J. Food Sci. 75, S108-S114. http://dx.doi.org/10.1111/j.1750-3841.2009.01475.x. 